O.V. Perlova ${ }^{1}$, Yu.S. Dzyazko ${ }^{2}$, A.A. Malinovska ${ }^{1}$, A.V. Palchik ${ }^{2}$

\title{
PECULIARITIES OF U(VI) SORPTION ON COMPOSITES CONTAINING HYDRATED TITANIUM DIOXIDE AND POTASSIUM-COBALT HEXACYANOFERRATE(II)
}

\author{
${ }^{1}$ Odessa I.I. Mechnikov National University \\ 2 Dvoryanska Str., Odesa, 65082,Ukraine, E-mail: olga_perlova@onu.edu.ua \\ ${ }^{2}$ Vernadsky Institute of General and Inorganic Chemistry of National Academy of Sciences of Ukraine \\ 32/34 Palladin Ave., Kyiv, 03142, Ukraine, E-mail: dzyazko@gmail.com
}

\begin{abstract}
As opposed to polymer sorbents, inorganic materials are stable against ionizing radiation. This gives a possibility to use them for the removal of radionuclides from water. As a rule, highly selective inorganic sorbents are obtained in a form of finely dispersive powder. This makes it difficult to use them in practice. Here the composites based on hydrated titanium dioxide containing $\mathrm{K}_{2} \mathrm{Co}\left[\mathrm{Fe}(\mathrm{CN})_{6}\right]$ have been developed. The modifier was inserted into partially (hydrogel) and fully (xerogel) formed oxide matrices. Modifying of hydrogel followed its transformation to xerogel provides the formation of potassium-cobalt hexacyanoferrate(II) nanoparticles (up to $10 \mathrm{~nm}$ ), which are not washed out in aqueous media due to encapsulation in hydrated oxide. A number of the methods for sample characterization were used in this work: transmission electronic microscopy for vizualization of embedded nanoparticles, optical microscopy to measure granule size, FT-IR spectroscopy, X-ray fluorescence spectroscopy for chemical analysis of the samples, potentiometric titration to estimate ion exchange properties, and spectrophotometric analysis of the solution to determine $U(V I)$ concentration. The features of U(VI) sorption from nitrate and sulfate solutions are considered: the effect of the sorbent dosage and solution composition was in a focus of attention. The influence of the modifier is the most pronounced at $\mathrm{pH} \geq 4$, when U(VI) is in a form of one-charged cations $\left(\mathrm{UO}_{2} \mathrm{OH}^{+}\right)$: the removal degree of $\mathrm{U}(\mathrm{VI})$ is close to $100 \%$. This positive effect of the selective constituent is expressed in a presence of an excess of $\mathrm{NO}_{3}{ }^{-}, \mathrm{SO}_{4}{ }^{2-}$ and $\mathrm{Na}^{+}$ions. The model of chemical reaction of pseudo second order has been applied to sorption. Both pristine sorbent and composite are most completely regenerated with a $0.1 \mathrm{M} \mathrm{KOH}$ solution - the regeneration degree is 92 and $96 \%$ respectively. In this case, the half-exchange time is minimal and equal to $\approx 23 \mathrm{~min}$ (initial hydrated titanium dioxide) and $47 \mathrm{~min}$ (composite). Desorption obeys the model of particle diffusion: the diffusion coefficients for ions being exchanged are (1.7-7.6) $\times 10^{-13} \mathrm{~m}^{2} \mathrm{~s}^{-1}$.
\end{abstract}

Keywords: Uranium(VI) compounds, hydrated titanium dioxide, potassium-cobalt hexacyanoferrate(II), sorption, nanoparticles

\section{INTRODUCTION}

Oxide materials are widely used as sorbents for removal of inorganic toxic impurities from water [1-3]. Both amorphous hydrous oxides [4-7] and crystalline [8-10] forms are involved to water purification and recovery of valuable components from aqueous solutions, since the materials possess considerable sorption capacity and selectivity. Oxides are also applied to modifying both inorganic [11-14] and polymer [15-18] membranes for electrodialytic [11-15] and baromembrane [16-18] separation. Inorganic modifiers enhance separation capability of the membranes and provide their stability against fouling of organic substances. However, oxide sorbents are very sensitive to $\mathrm{pH}$ : decrease of the solution acidity causes enhancement of cation exchange properties and weakening anion exchange capability. On the contrary, they possess mainly anion exchange properties in acidic solutions. This is very important in the case of the compounds of $f$-metals: their speciation strongly depends on the solution composition.

In order to minimize the sensitivity of oxides of multivalent metals to the solution $\mathrm{pH}$, the composites containing these materials are prepared. Inorganic ion-exchangers can be inserted to ion exchange resins: the improvement of their selectivity and acceleration of sorption can be reached by this manner [19-22]. The composites are used not only in traditional ion exchange [19-22], but also in combining processes of electrodialysis-ion exchange [23]. Functionalization of the surface of oxide materials enhances their sorption 
properties [24-28], conjoining magnetic particles with other sorbents allows us to facilitate separation of liquid and solid [29-33]. Other way is the development of inorganic composites based on oxide materials: they are attractive for radionuclide sorption due to stability against ionizing radiation in comparison with the composites including organic constituents. They are also stable against fouling with organic substances - this facilitates regeneration of the sorbents and provides their multiple usage. For instance, oxide-based composites containing oxidized graphene have been proposed for the removal of $\mathrm{U}(\mathrm{VI})$ compounds [34,35], arsenate [36], phosphate [37], sulfide [38], $\mathrm{Pb}^{2+}, \mathrm{Hg}^{2+}$ and $\mathrm{Cu}^{2+}$ [39] ions from water, $\mathrm{Na}^{+}, \mathrm{K}^{+}, \mathrm{Ca}^{2+}$ and $\mathrm{Mg}^{2+}$ ions from milky whey [40], as well as for photocatalytic degradation of dyes [41]. In these cases, incorporated graphene particles perform a function of additional sorption centers. The oxide matrices play a role of both sorbent and binder. The composites are more attractive comparing with graphene, since this carbon nanomaterial is obtained only in finely dispersive form and cannot be used in ion exchange columns.

A number of highly selective sorbents, such as lithium-containing spinel or hexacyanoferrates are finely dispersive powders: the development of the oxide-based composites allows us to overcome these difficulties. Three ways, which allow us to create inorganic composites, are possible: (i) simultaneous formation of selective component and binder, (ii) synthesis of the selective constituent in the preliminary formed oxide matrix, (iii) framing of the particles of selective sorbent with binder. Earlier Li-selective sorbents were synthesized using (i) [8] and (iii) methods [7]. The (ii) direction was taken into consideration to prepare composite inorganic membranes [11-14]; the (iii) way was applied to synthesize graphene-containing composites [34, 35].

Among selective sorbents, insoluble hexacyanoferrates(II) occupy special position due to high selectivity towards $\mathrm{Cs}^{+}$ions [41-46] - this property is very important for radionuclide sorption. For instance, in the case of insoluble Prussian Blue $\mathrm{Fe}_{4}\left[\mathrm{Fe}(\mathrm{CN})_{6}\right]_{3}$ containing $\mathrm{Fe}(\mathrm{II})$ and $\mathrm{Fe}(\mathrm{III})$ atoms, they alternate in the sites of a face-centered cubic lattice, and are bonded through cyan groups $[47,48]$. As known, the selectivity of Prussian Blue is due to regular lattice voids, which are surrounded by $\mathrm{CN}$-bridged $\mathrm{Fe}$ atoms. The voids are traps for $\mathrm{Cs}^{+}$ions; their uptake is caused by simple physical adsorption. Positive charge of cations is compensated by anions adsorbed on crystallites. Other way is sorption via protons $\left(\mathrm{Cs}^{+} \rightarrow \mathrm{H}^{+}\right.$ exchange), which exist in lattice defects containing $-\mathrm{OH}$ groups and coordination water. In order to increase a number of vacancies, analogues of Prussian Blue containing other metals are used [42-46], Formation of additional Cs-containing phases during sorption has been suggested [46].

Cyanoferrates are also promising as sorbents for $\mathrm{Rb}^{+}$[45-49] and $\mathrm{Tl}^{+}[42,50]$. Sorption of $\mathrm{U}(\mathrm{VI})$ compounds on the sorbent, the composition of which is $\mathrm{Zn}_{4} \mathrm{Al}_{2}(\mathrm{OH})_{12}\left[\mathrm{Fe}(\mathrm{CN})_{6}\right]_{0.5} \cdot 8 \mathrm{H}_{2} \mathrm{O}$, has been reported [51]. Prussian Blue is also capable to sorb U(VI) ions, however, its capacity is 2 times smaller than that for $\mathrm{Cs}^{+}$ions [52]. Earlier we have obtained, characterized and tested oxide-based composite containing $\mathrm{K}_{2} \mathrm{Co}\left[\mathrm{Fe}(\mathrm{CN})_{6}\right]$ nanoparticles [53]: the modifier has been found to improve sufficiently U(VI) sorption on oxide matrix. The aim of this investigation is to elucidate the regularities of U(VI) uptake: the effect of the sorbent dosage and the solution composition on sorption and desorption has been considered.

Cyanoferrates are the constituents of a number of composites for radionuclide sorption: they are based on clay minerals [54-56], silica [57-59], plant cellulose [60-62], activated carbon [63-66] etc. For the composite preparation, we used hydrated titanium oxide as a matrix since the materials of this type possess considerable sorption capacity towards both cations and anions. Depending on the solution composition, U(VI) compounds are cationic, anionic or neutral.

\section{EXPERIMENTAL}

The method of synthesis of hydrated titanium dioxide and its composites containing $\mathrm{K}_{2} \mathrm{Co}\left[\mathrm{Fe}(\mathrm{CN})_{6}\right]$ was described in detail in [53]. Briefly: sol was synthesized electrochemically by electrodialysis of a chloride solution containing $\mathrm{Ti}$ $\left.(1 \mathrm{~mol} \mathrm{dm})^{-3}\right)$ and also $\mathrm{Zr}\left(0.05 \mathrm{~mol} \mathrm{dm}^{-3}\right)$ for stabilization $[53,66]$. When $\mathrm{Cl}^{-}$ions were partially removed, the colloidal solution of insoluble hydroxocomplexes was formed. The granules of 
oxide hydrogel were formed in a medium of nonpolar solvent just after deposition with a $1 \mathrm{M} \mathrm{NH}_{4} \mathrm{OH}$ solution. Hydrogel was washed with deionized water, a part of it was dried at $20-25^{\circ} \mathrm{C}$. Xerogel of hydrated zirconium dioxide (further HTD) was obtained in this manner.

First of all, the (ii) direction (see above) was applied to the synthesis of composite, i.e. the selective constituent was deposited in the preliminary formed matrix. However, the oxide matrix was formed only partially. Potassium-cobalt hexacyanoferrate(II) was obtained by mixing a $0.5 \mathrm{M} \mathrm{K}_{4}\left[\mathrm{Fe}(\mathrm{CN})_{6}\right]$ and a $3 \mathrm{M} \mathrm{Co}\left(\mathrm{NO}_{3}\right)_{2}$ solutions, when the ratio of their volumes was 1:2.4 (these conditions are suggested in [49]). The deposition was carried out in a presence of hydrogel, the ratio of volumes of hydrogel and reaction mixture was $1: 100$. As found, namely this ratio allows us to obtain large granules [53]. The composite was washed with deionized water and dried under ambient conditions. The sample was marked as HTD-KCoFCN-1.

The same procedure was applied to obtain the HTD-KCoFCN-2 sample. In this case, the oxide matrix was fully formed. In other words, HTD xerogel was inserted into the reaction mixture instead of hydrogel.

The methods of sample characterization and investigation results are described in detail earlier [53]. Such equipment was used: a JEOL JEM 1230 transmission microscope (JEOL, Japan) for TEM observation, a Crystal-45 optical microscope (Konus, USA) to measure granule size, a Spectrum BX FT-IR spectrometer (Perkin Elmer, USA) to obtain FTIR spectra, a Quantachrome Autosorb 6B device (Quantachrome Instruments, USA) to determine some parameters of porous structure. Chemical analysis of the samples was performed with an $\mathrm{X}$-Supreme8000 XRF (X-ray fluorescence) spectrometer (Oxford Instruments).

Potentiometric titration was carried out as follows. A series of weighted samples were in contact with $0.1 \mathrm{M} \mathrm{NaCl}$ solutions containing different amounts of $\mathrm{HCl}$ or $\mathrm{NaOH}$. The $\mathrm{pH}$ was measured before and after sorption with an I-160MI pH meter (Analitpribor, RF).

Before the research, the samples were sieved; a fraction of $0.25-0.5 \mathrm{~mm}$ was taken. A $0.1 \mathrm{M}$ solution of $\mathrm{U}(\mathrm{VI})$-compounds was prepared using an $\mathrm{UO}_{2}\left(\mathrm{CH}_{3} \mathrm{COO}\right)_{2} \cdot 2 \mathrm{H}_{2} \mathrm{O}$ salt. During the solution preparation, it was acidified with nitric or sulfuric acid down to $\mathrm{pH} 2$. Then the solution $\mathrm{pH}$ was alkalized to the required level $(3,5$ etc. $)$ with a $\mathrm{NaOH}$ solution. The solutions with lower U(VI) content were prepared in a similar manner.

The uptake of U(VI) compounds was determined by means of spectrophotometric analysis of the solution using a Shimadzu UV-mini1240 device (Shimadzu, Japan). Arsenazo III was used for bonding U(VI) in a complex [67]. The solution being analyzed was preliminarily acidified; the measurements were performed at $670 \mathrm{~nm}$. The removal degree $(S)$ of $\mathrm{U}(\mathrm{VI})$ species and sorption capacity $(A)$ of the samples were calculated using the formulas:

$$
\begin{aligned}
& S=\frac{C_{i}-C_{e}}{C_{i}} \times 100 \% \\
& A=\frac{V\left(C_{i}-C_{e}\right)}{m},
\end{aligned}
$$

where $V$ is the volume of the solution, $C_{i}$ and $C_{e}$ are the initial and equilibrium concentrations respectively, $m$ is the mass of the sample.

When sorption experiments were performed, the maximal time of the contact between the solid and liquid was $48 \mathrm{~h}$. As found, this period is enough to reach sorption equilibrium.

First series of the experiments provided the clarification of the dosage effect on U(VI) sorption. The initial solution $\mathrm{pH}$ was 2 , the

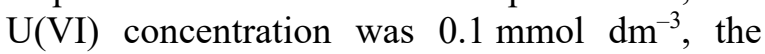
dosage was varied from 0.5 to 4 . In other cases, the sorbent dosage was $2 \mathrm{~g} \mathrm{dm}^{-3}$.

When the sorption rate was investigated, the initial concentration of U(VI) compounds was $0.1 \mathrm{mmol} \mathrm{dm}^{-3}$, the $\mathrm{pH}$ was varied from 2 to 10 . Probes $\left(1 \mathrm{~cm}^{3}\right)$ of the solution, which was shacked intensively with a Water Bath Shaker Type 357 system (Elpan, Poland), were taken regularly for further analysis.

The effect of the initial solution

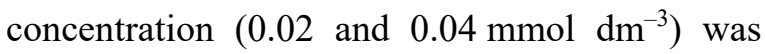
researched in similar manner. In this case, the initial solution $\mathrm{pH}$ was 5 .

For desorption, $0.1 \mathrm{M} \mathrm{K}_{2} \mathrm{CO}_{3}, \mathrm{KHCO}_{3}$ and $\mathrm{KOH}$ solutions were used. Preliminarily the sorbents were loaded with $\mathrm{U}(\mathrm{VI})$ up to the capacity of $0.5 \mathrm{mmol} \mathrm{g}^{-1}$.

\section{RESULTS AND DISCUSSION}

Characterization of the sorbents is described in detail in [53]. Here main results are given briefly. When the modifier was obtained in the 
absence of HTD, its composition was found by X-ray analysis (see [53]). Regarding the composites, the molar ratios of $\mathrm{K}: \mathrm{Co}$ and $\mathrm{Co}: \mathrm{Fe}$ are $\approx 2: 1$ and $1: 1$ respectively (Table 1 ) indicating the modifier composition as $\mathrm{K}_{2} \mathrm{Co}\left[\mathrm{Fe}(\mathrm{CN})_{6}\right]$. Moreover, characteristic stripe, which is attributed to cyan groups, is observed in
FTIR spectra (see further and also [53]). Comparing with the HTD-KCoFCN-1 sample, lower $\mathrm{K}: \mathrm{Ti}$ and $\mathrm{Co}$ :Ti ratios have been found for the HTD-KCoFCN-2 sorbent. It means lower modifier content in the sample obtained by xerogel modifying.

Table 1. Characteristics of HTD-based samples

\begin{tabular}{|c|c|c|c|c|c|c|c|}
\hline \multirow{2}{*}{ Sample } & \multicolumn{4}{|c|}{ Molar ratio } & \multicolumn{2}{|c|}{ Pore volume, $\mathrm{cm}^{3} \mathrm{~g}^{-1}$} & \multirow{2}{*}{$\begin{array}{l}\text { Specific surface } \\
\text { area, } \mathbf{m}^{2} \mathbf{g}^{-1}\end{array}$} \\
\hline & K:Co & $\mathrm{Co}: \mathrm{Fe}$ & $\mathrm{K}: \mathrm{Ti}$ & Co:Ti & micropores & mesopores & \\
\hline HTD & & & & & 0.04 & 0.28 & 161 \\
\hline $\begin{array}{c}\text { HTD- } \\
\text { KCoFCN-1 }\end{array}$ & $2.03: 1$ & $1.05: 1$ & $0.39: 1$ & $0.19: 1$ & 0.06 & 0.34 & 198 \\
\hline $\begin{array}{c}\text { HTD- } \\
\text { KCoFCN-2 }\end{array}$ & $1.95: 1$ & $1.02: 1$ & $0.21: 1$ & $0.10: 1$ & 0.05 & 0.29 & 175 \\
\hline
\end{tabular}

The granule size depends on the form of oxide matrix, to which the modifier was inserted. As seen in Fig. 1, its insertion to the HTD hydrogel causes the formation of slightly smaller granules (HTD-KCoFCN-1) in comparison with HTD. The nanoparicles of the modifier, which are more contrast comparing with titanium oxide, are seen in Fig. 2. The nanoparticles are spherical; their size is up to $10 \mathrm{~nm}$. Comparing with HTD, no sufficient change of granule size was found for the HTD-KCoFCN-2 sample, which was obtained by modifying HTD xerogel (see Fig. 1). No modifier nanoparticles were found for the HTD-KCoFCN-2 sorbent. It means their aggregation in xerogel macropores, or the formation of large particles in these voids. The aggregate formation is confirmed by an increase of micro-, mesoporosity and specific surface area of HTD-KCoFCN-2 comparing with HTD. The largest volume of micro- and mesopores, and the most developed surface have been found for the HTD-KCoFCN-1 sample. Both the composition of materials and their morphological features determine their sorption properties.

The behavior of HTD in $\mathrm{NaCl}$ solutions is typical for oxide materials as shown from the difference between the initial and equilibrium $\mathrm{pH}$ $\left(\mathrm{pH}_{\mathrm{i}}\right.$ and $\mathrm{pH}_{\mathrm{e}}$ respectively), $\Delta \mathrm{pH}$ (Fig. 3). HTD predictably shows cation exchange properties in alkaline media (positive $\Delta \mathrm{pH}$ values) and anion exchange capability (negative $\Delta \mathrm{pH}$ ). The point of zero charge (PZC) is observed about $\mathrm{pH} 6$. The modifier does not affect the PZC position sufficiently, since it contains no $\mathrm{H}^{+}$or $\mathrm{OH}^{-}$ions, which could be substituted by $\mathrm{Na}^{+}$cations or $\mathrm{Cl}^{-}$ anions.

The $\Delta \mathrm{pH}-\mathrm{pH}_{\mathrm{i}}$ curves show a minimum at $\mathrm{pH}$ 4. This is a result of competition of several reasons. First of all, anion exchange occurs:

$\equiv \mathrm{Ti}-\mathrm{OH}+\mathrm{H}^{+}+\mathrm{Cl}^{-} \rightarrow \equiv \mathrm{Ti}-\mathrm{OH}_{2}{ }^{+} \mathrm{Cl}^{-}$.

This results in bonding of $\mathrm{H}^{+}$ions (an increase of $\mathrm{pH})$. On the other hand, $\mathrm{NH}_{4}{ }^{+}$ cations, which were sorbed during HTD deposition, are released:

$\equiv \mathrm{Ti}-\mathrm{O}^{-} \mathrm{NH}_{4}{ }^{+}+2 \mathrm{H}^{+}+2 \mathrm{Cl}^{-} \rightarrow \equiv \mathrm{Ti}-\mathrm{OH}_{2}^{+} \mathrm{Cl}^{-}+\mathrm{NH}_{4}{ }^{+}+\mathrm{Cl}^{-}$.

Desorption of ammonium ions also causes the increase of $\mathrm{pH}$. Simultaneously, hydrolysis leads to acidification:

$\mathrm{NH}_{4}{ }^{+}+\mathrm{H}_{2} \mathrm{O} \rightarrow \mathrm{NH}_{4} \mathrm{OH}+\mathrm{H}^{+}$.

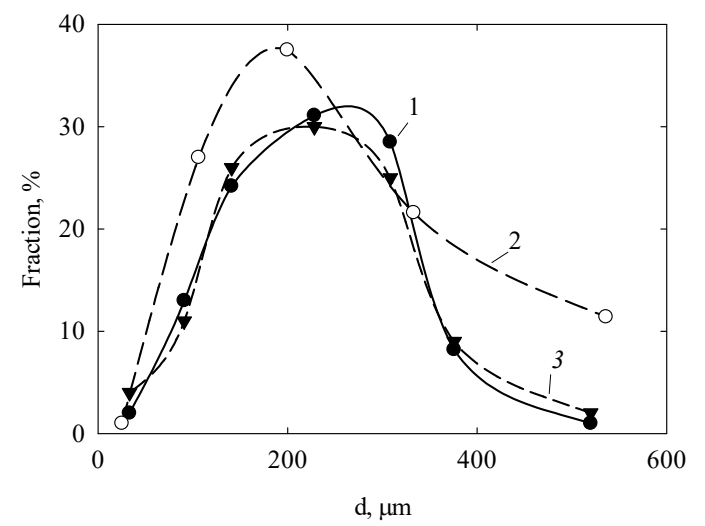

Fig. 1. Granule size distributions for $\operatorname{HTD}(1)$, HTD-KCoFCN-1 (2), HTD-KCoFCN-2 (3) 


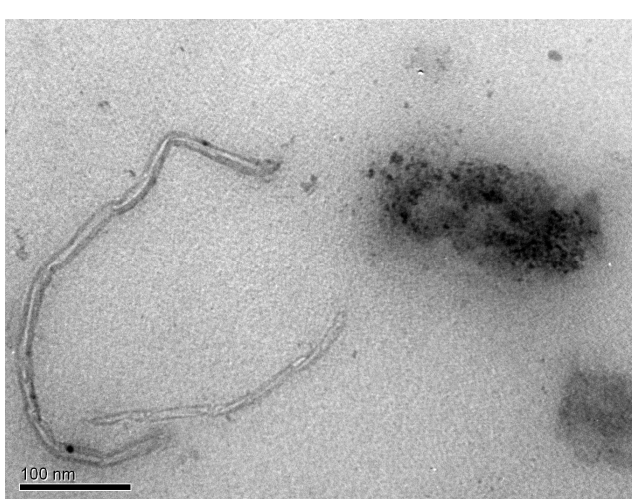

Fig. 2. TEM image of HTD-KCoFCN-1

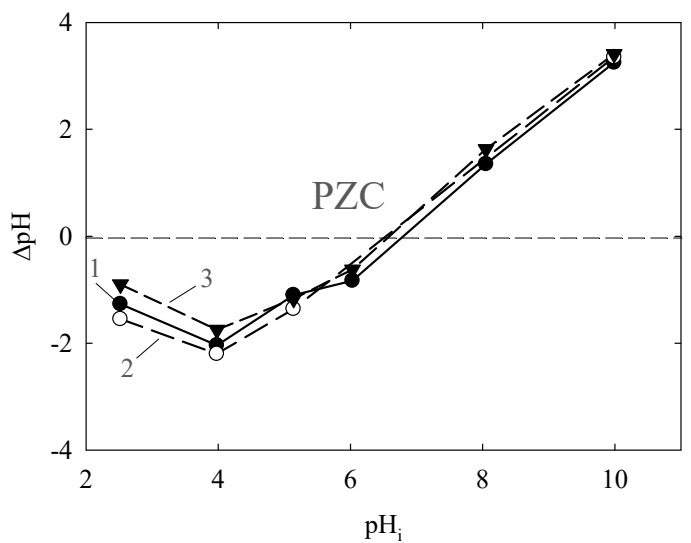

Fig. 3. The shift of the $\mathrm{pH}$ as a function of $\mathrm{pH}_{\mathrm{i}}$. Sorbents: HTD (1), HTD-KCoFCN-1 (2), HTD-KCoFCN-2 (3)

A presence of ammonium in sorbents is confirmed by FTIR spectroscopy (see further). Within the interval of $\mathrm{pH} 2-4$, the $\Delta \mathrm{pH}$ value decreases in the order: HTD-KCoFCN-1 > HTD $>$ HTD-KCoFCN-2. In other words, the HTD-KCoFCN-2 sample binds $\mathrm{H}^{+}$ions most weakly. At $\mathrm{pH} \mathrm{6,} \mathrm{the} \mathrm{order} \mathrm{is} \mathrm{as} \mathrm{follows:}$ HTD-KCoFCN-2 > HTD-KCoFCN-1 > HTD, however, the difference in $\mathrm{pH}$ shifts is not too sufficient. At $\mathrm{pH}>6$, cation exchange dominates:

$\equiv \mathrm{Ti}-\mathrm{O}^{-} \mathrm{H}^{+}+\mathrm{Na}^{+} \rightarrow \equiv \mathrm{Ti}-\mathrm{O}^{-} \mathrm{Na}^{+}+\mathrm{H}^{+}$;

$\equiv \mathrm{Ti}-\mathrm{O}^{-} \mathrm{NH}_{4}{ }^{+}+\mathrm{Na}^{+} \rightarrow \equiv \mathrm{Ti}-\mathrm{O}^{-} \mathrm{Na}^{+}+\mathrm{NH}_{4}{ }^{+}$.

These two ways provide a shift of the $\mathrm{pH}$ to acidic region due to $\mathrm{H}^{+}$release on the one hand and hydrolysis of $\mathrm{NH}_{4}{ }^{+}$ions on the other hand. No change of the $\mathrm{pH}$ occurs due to modifier. The HTD-KCoFCN-2 sample evidently contains larger amount of ammonium due to higher content of $\equiv \mathrm{Ti}-\mathrm{OH}$ groups. This is caused by smaller content of the modifier in comparison with the HTD-KCoFCN-1 sorbent. As a result, the largest shift of the $\mathrm{pH}$ to alkaline region is observed. The smallest shift in the case of HTD is probably due to less developed surface: less amount of groups are available to ion exchange.

Acidic-basic properties of the sorbents provide their behaviour over U(VI) sorption in a wide range of $\mathrm{pH}$.

Other important factor is the speciation of $\mathrm{U}(\mathrm{VI})$ ions. The forms of uranyl ions are determined by the solution composition (Table 2) [68, 69]. Depending on the solution $\mathrm{pH}$, one or another type of ions dominates, i.e. its content exceeds $40-50 \% . \quad \mathrm{UO}_{2}{ }^{2+}$ cations dominate in both nitrate and sulfate solutions within the $\mathrm{pH}$ interval of 2-5 (nitrate) and 2-4 (sulfate). Regarding nitrate media, the content of cationic $\left[\mathrm{UO}_{2} \mathrm{OH}\right]^{+}$forms is considerable at $\mathrm{pH}$ 5-8. Under these conditions, the content of $\left[\mathrm{UO}_{2} \mathrm{OH}\right]^{+}$cations is lower in sulfate solutions. In both media, neutral insoluble $\mathrm{UO}_{2}(\mathrm{OH})_{2}$ exists in colloidal form at $\mathrm{pH} 5$ and higher. At the same time, neutral soluble $\mathrm{UO}_{2} \mathrm{SO}_{4}$ form dominates in sulfate solution at $\mathrm{pH} 2-4$ together with $\mathrm{UO}_{2}{ }^{2+}$ cations, the content of anionic forms is inconsiderable under these conditions. Speciation of ionic forms is one of the reasons that provide wave-like dependences of sorption on the solution $\mathrm{pH}[34,35,53]$.

Speciation of U(VI) as well as acidic-basic properties of sorbents determine the features of sorption under different $\mathrm{pH}$. For the sample testing, the effect of the $\mathrm{pH}$ of sulfate solutions on U(VI) sorption was examined (Fig. 4). As opposed to $\mathrm{Na}^{+}$and $\mathrm{Cl}^{-}$sorption, the curves are characterized by the rapid increase within the $\mathrm{pH}_{\mathrm{i}}$ interval of 4-6 (the equilibrium $\mathrm{pH}$ is about 6). Namely, under these conditions the content of charged forms is maximal.

Both composites show higher sorption capacity in comparison with HTD. This can be explained by the modifier effect. $\mathrm{K}^{+}$ions were found in equilibrium solutions, it means ion exchange:

$\mathrm{K}_{2} \mathrm{Co}\left[\mathrm{Fe}(\mathrm{CN})_{6}\right]+\mathrm{UO}_{2}^{2+} \rightarrow \mathrm{UO}_{2} \mathrm{Co}\left[\mathrm{Fe}(\mathrm{CN})_{6}\right]+2 \mathrm{~K}^{+}$.

If we compare two composites, the HTD$\mathrm{KCoFCN}-2$ sample shows higher capacity then the HTD-KCoFCN-1 sorbent at $\mathrm{pH}<4$ due to stronger alkalization of the solution. For instance, when $\mathrm{pH}_{\mathrm{i}}$ was 3 , the equilibrium value 
reached 5 (HTD-KCoFCN-2) and 6 (HTD$\mathrm{KCoFCN}-1) . \mathrm{UO}_{2}{ }^{2+}$ ions dominate at $\mathrm{pH} 5$, $\left[\mathrm{UO}_{2} \mathrm{OH}\right]^{+}$species prevail at $\mathrm{pH} 6$. As a rule, doubly charged ions are better sorbed than singly charged species. In neutral media, the largest capacity has been found for the HTD-KCoFCN-1 sample. In this case, no change of initial $\mathrm{pH}$ has been found. So, an increase of U(VI) uptake can be explained by the effect of $\mathrm{K}_{2} \mathrm{Co}\left[\mathrm{Fe}(\mathrm{CN})_{6}\right]$ (see eq. 8).

Table 2. Speciation of U(VI) compounds (based on the analysis of [68, 69] data)

\begin{tabular}{|c|c|c|c|c|c|c|c|c|c|}
\hline \multirow[t]{2}{*}{ pH } & \multicolumn{3}{|c|}{$\begin{array}{c}\text { Nitrate solutions, fraction of } \\
\text { species, } \%\end{array}$} & \multicolumn{6}{|c|}{ Sulfate solutions, fraction of species, $\%$} \\
\hline & $\mathrm{UO}_{2}{ }^{2+}$ & {$\left[\mathrm{UO}_{2}{ }^{2+} \mathrm{OH}\right]^{+}$} & $\mathrm{UO}_{2}(\mathrm{OH})_{2}$ & $\mathrm{UO}_{2}{ }^{2+}$ & {$\left[\mathrm{UO}_{2} \mathrm{SO}_{4}\right]$} & {$\left[\mathrm{UO}_{2}\left(\mathrm{SO}_{4}\right)_{2}\right]^{2-}$} & {$\left[\mathrm{UO}_{2}\left(\mathrm{SO}_{4}\right)_{3}\right]^{4-}$} & {$\left[\mathrm{UO}_{2} \mathbf{O H}\right]^{+}$} & $\mathrm{UO}_{2}(\mathrm{OH})_{2}$ \\
\hline 2 & 100 & 0 & 0 & 47 & 45 & 7 & 1 & & \\
\hline 3 & 95 & 5 & 0 & 47 & 45 & 7 & 1 & & \\
\hline 4 & 85 & 15 & 0 & 45 & 43 & 6 & 1 & 5 & \\
\hline 5 & 45 & 45 & 10 & 32 & 30 & 4 & 1 & 31 & 2 \\
\hline 6 & 15 & 70 & 15 & 7 & 3 & 1 & 1 & 54 & 34 \\
\hline 7 & 3 & 37 & 60 & 1 & 1 & & & 12 & 86 \\
\hline 8 & 0 & 15 & 85 & & & & & 2 & 98 \\
\hline 9 & 0 & 2 & 98 & & & & & 1 & 99 \\
\hline 10 & 0 & 0 & 100 & & & & & & 100 \\
\hline
\end{tabular}

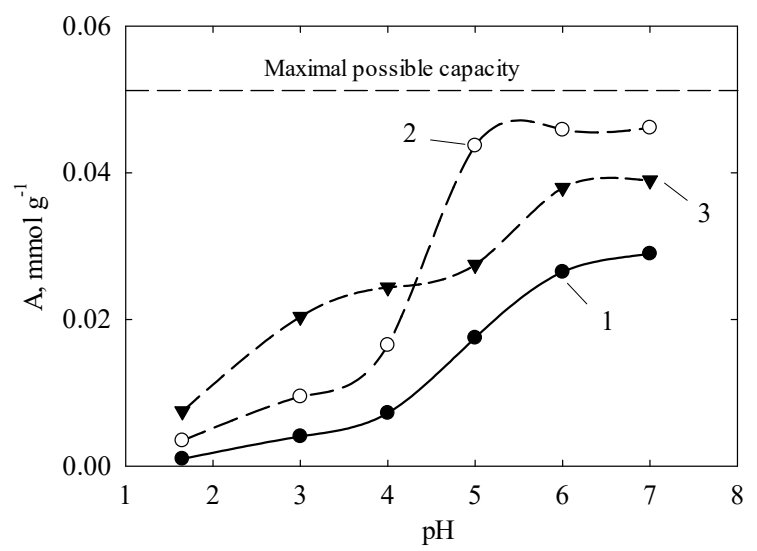

Fig. 4. Effect of $\mathrm{pH}$ on U(VI) sorption on HTD (1), HTD-KCoFCN-1 (2), HTD-KCoFCN-2 (3)

Thus, the effect of the $\mathrm{UO}_{2}{ }^{2+} \rightarrow\left[\mathrm{UO}_{2} \mathrm{OH}\right]^{+}$ transformation plays a key role at low initial $\mathrm{pH}$. This transformation is due to the solution alkalization that is caused by anion exchange on oxide matrix and ammonium hydrolysis. In neutral media, the modifier effect is manifested.

It should be noted that the modifier particles, which had been inserted into xerogel, were removed from the granules of HTD-KCoFCN-2. After sorption, the molar ratio of Co:Ti was 0.04, it means a loss of the modifier particles. They are evidently located in microcracks on the granule surface, from which they are washing out easy. Further this sample was not examined. At the same time, the HTD-KCoFCN-1 sample demonstrates stability of the modifier, since its nanoparticles are encapsulated inside granule.
Normally the removal degree of the solution component is determined by the sorbent dosage: the higher this parameter, the deeper the purification. Fig. 5 illustrates the influence of dosage on U(VI) sorption. In the case of nitrate solution $\left(\mathrm{pH}_{\mathrm{i}} 2\right)$, the removal degree expectedly increases with dosage reaching a plateau. Equilibrium $\mathrm{pH}$ was within the interval of 2.1-2.4: $\mathrm{UO}_{2}{ }^{2+}$ cations exist in the solution under these conditions. However, cation exchange capability of oxide matrix is depressed. As a result, the removal degree of $\mathrm{U}(\mathrm{VI})$ is up to $20-40 \%$.

The dependence of the $S$ value on dosage, which was obtained for sulfate solution at $\mathrm{pH}_{\mathrm{i}} 6$, also shows a growth followed by a plateau (HTD-KCoCF-1). For unmodified HTD, the 
curve demonstrates a maximum at $2 \mathrm{~g} \mathrm{dm}^{-3}$ $\left(\mathrm{pH}_{\mathrm{e}}\right.$ 6.5). When the dosage exceeds this value, the $\mathrm{pH}_{\mathrm{e}}$ is about 7 - neutral $\mathrm{U}(\mathrm{VI})$ species dominate under these conditions, cation exchange capability of oxide matrix is insufficient. Regarding the composite, sorption is enhanced by the modifier.

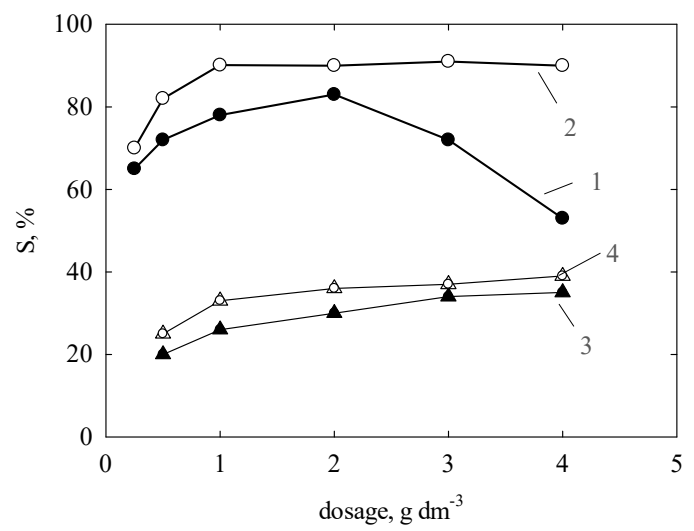

Fig. 5. Effect of the sorbent dosage on the removal degree of U(VI) ions from sulfate solution at $\mathrm{pH}_{\mathrm{i}} 6(1,2)$ and nitrate solution at $\mathrm{pH}_{\mathrm{i}} 2(3,4)$. Sorbents: HTD $(1,3)$, HTD-KCoCF-1 $(2,4)$
Acidity of the solution also affects the rate of sorption of U(VI) compounds on hydrous oxides and their composites [34]. Here the effect of the $\mathrm{pH}$ on sorption from nitrate solutions is studied, since charged forms of species prevail in a wide interval of $\mathrm{pH}$ (Fig. 6). The degree of U(VI) removal vs time $(t)$ is given in Fig. $6 a$ for several $\mathrm{pH}_{\mathrm{i}}$. The curves are typical: they show rapid increase followed by a plateau.

As shown from Fig. $6 b$, the model of chemical reaction of pseudo-second order is the most suitable for describing the data (Fig. $6 b$ ) [70]:

$$
\frac{t}{A}=\frac{1}{K_{2} A_{\infty}^{2}}+\frac{1}{A_{\infty}} \cdot t
$$

Here $A_{\infty}$ is the sorption capacity, when $t \rightarrow \infty, K_{2}$ is the rate constants. The $t / A$ curves can be successfully linearized; the correlation coefficient is $0.98-0.99$. The application of the "pseudo-order" model means much higher amount of sorption centers than U(VI) species in a solution.
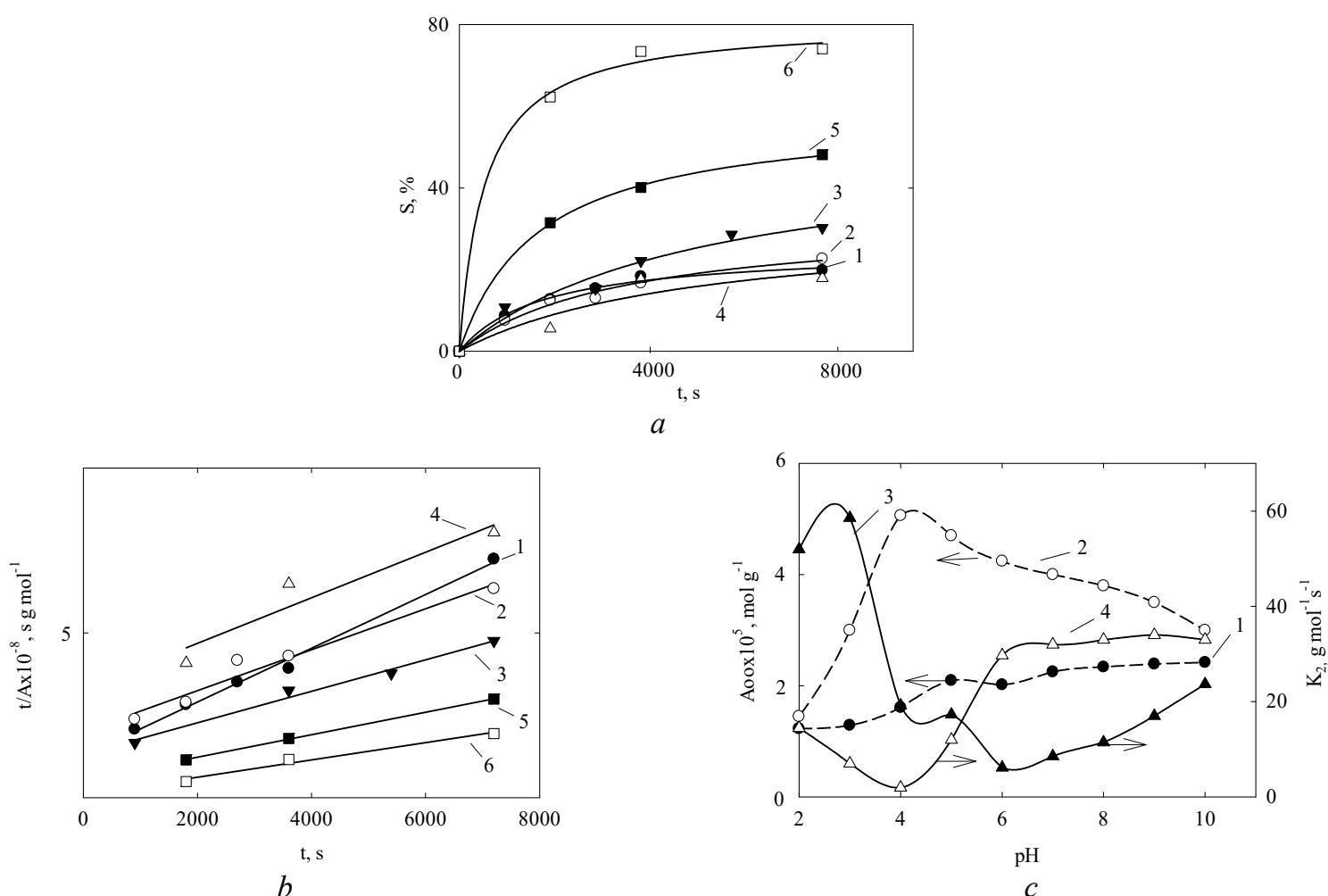

Fig. 6. Effect of $\mathrm{pH}_{\mathrm{i}}$ on the sorption rate of U(VI) compounds: removal degree of U(VI) ions as a function of time $(a)$, application of the model of pseudo-second order $(b), A_{\infty}(1 c, 2 c)$ and $K_{2}(3 c, 4 c)$ constants as functions of pH. Sorbents: HTD $(1 a, b-3 a, b ; 1 c, 3 c)$, HTD-KCoFCN-1 $(4 a, b-6 a, b ; 2 c, 4 c), \mathrm{pH}_{\mathrm{i}} 2(a, b-1,4), 4(a, b$ $-2,5), 6(a, b-3,6)$. The data of Fig. $6 a, b$ are given only up to $2 \mathrm{~h}$ for clarity 
The $A_{\infty}$ constants, which are in a good agreement with experimental data, are represented in Fig. $6 c$. In the case of HTD, the $A_{\infty}-\mathrm{pH}$ curve shows a rapid increase at $\mathrm{pH}_{\mathrm{i}} 3-5$, where charged forms dominate. Further slight increase of sorption capacity is due to the enhancement of cation exchange capability of hydrous oxide. In alkaline media, sorption of $\mathrm{Na}^{+}$ ions is accompanied by acidification (see Fig. 3). As a result, neural U(VI) species are transformed into cations.

Regarding the composite, much higher $A_{\infty}$ values have been found evidently due to exchange (8). The maximum of the $A_{\infty}-\mathrm{pH}_{\mathrm{i}}$ curve is due to competition of two factors: enhancement of cation exchange ability of HTD on the one hand and an increase of the concentration of neutral $\mathrm{UO}_{2}(\mathrm{OH})_{2}$ form on the other hand. At $\mathrm{pH} 4-5$, sorption capacity is close to the maximal possible value $\left(0.5 \mathrm{mmol} \mathrm{\textrm {dm } ^ { - 3 }}\right.$

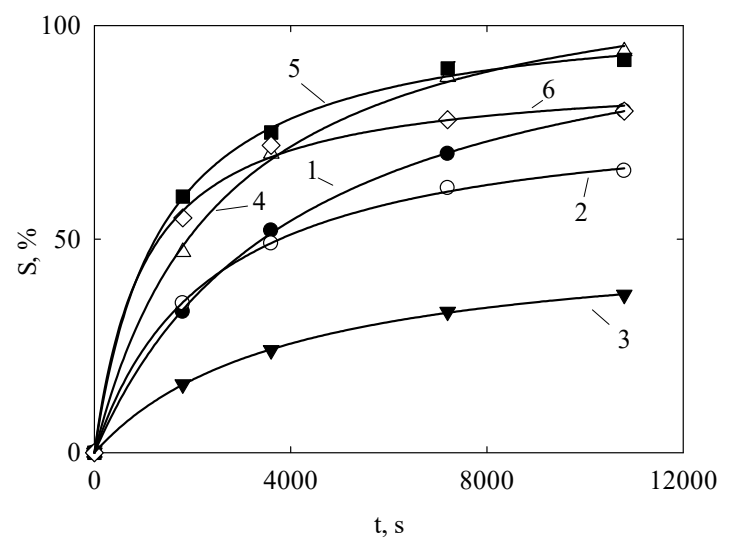

$a$

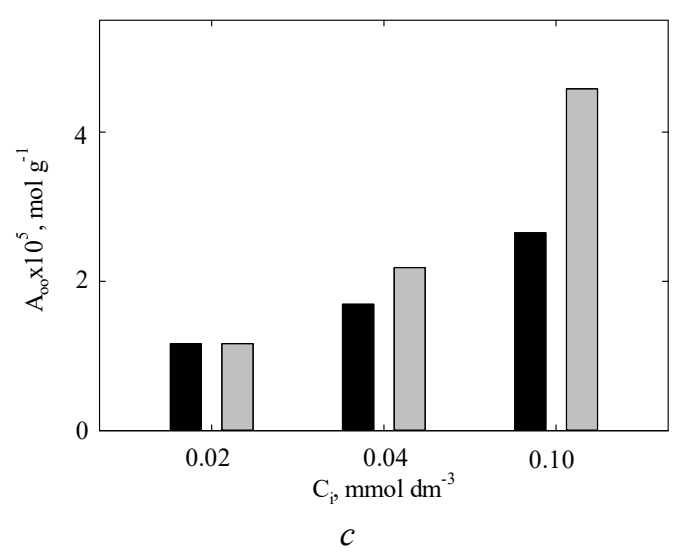

taking into consideration the amount of $\mathrm{U}(\mathrm{VI})$ in the solution, and sorbent mass).

The constant rate for the composite is lower than that for HTD $\left(\mathrm{pH}_{\mathrm{i}} 2-5\right)$ probably due to slower exchange of $\mathrm{UO}_{2}{ }^{2+} \rightarrow \mathrm{K}^{+}$comparing with $\left[\mathrm{UO}_{2} \mathrm{OH}\right]^{+} \rightarrow \mathrm{K}^{+}$. Under higher $\mathrm{pH}$, sorption on the composite becomes slightly faster. A minimum of the $K_{2}-\mathrm{pH}_{\mathrm{i}}$ curve is due to the competition of two factors: an increase of the content of $\left[\mathrm{UO}_{2} \mathrm{OH}\right]^{+}$form instead of $\mathrm{UO}_{2}{ }^{2+}$ (acceleration of sorption) and a growth of dissociation degree of $\equiv \mathrm{Ti}-\mathrm{OH}$ groups (enhancement of cation exchange properties that causes retardation of sorption).

Similarly, the model of pseudo-second order can be applied to the kinetic curves, which were obtained under different U(VI) concentration. In all cases, the modifier increases sorption capacity and accelerates sorption.

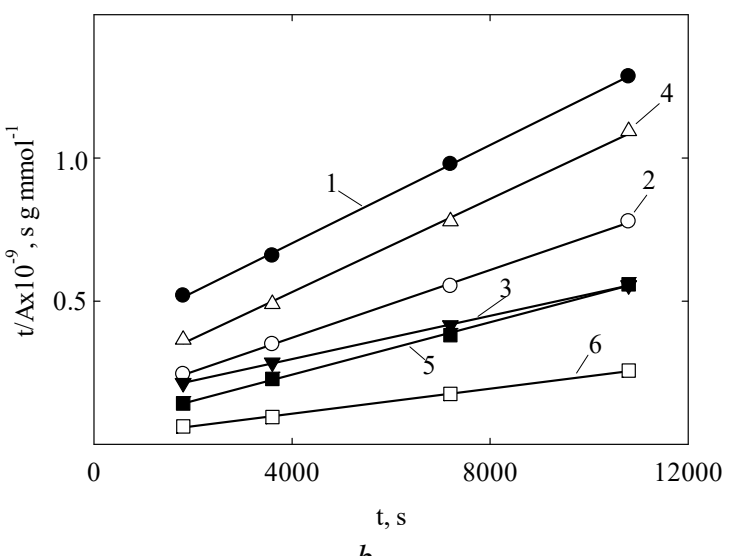

$b$

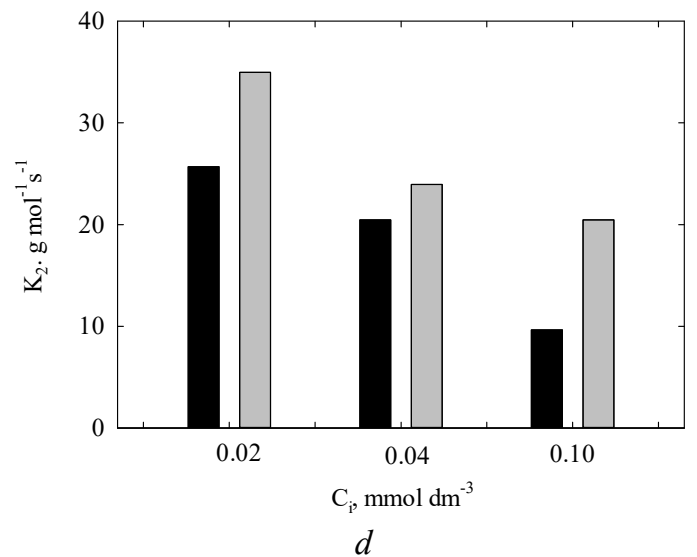

$d$

Fig. 7. Effect of the initial concentration of U(VI) compounds on their sorption rate: removal degree of U(VI) as a function of time (a), application of the model of pseudo-second order (b), the $A_{\infty}(c)$ and $K_{2}(d)$ parameters for different initial concentrations of U(VI) in nitrate solution (pH 6). Sorbents: HTD $(1 a, b-3 a, b)$, dark bars $(c, d)$, HTD- KCoFCN-1 (4 $a, b-6 a, b)$, light bars $(c, d)$ 
Chemical interactions of ions with functional groups of HTD are confirmed by the data of FTIR spectroscopy (Fig. 8). In this figure, the spectra both for the pristine samples and sorbents containing U(VI) $\left(0.5 \mathrm{mmol} \mathrm{g}^{-1}\right)$ are given. The stripes at $>3000 \mathrm{~cm}^{-1}$ are attributed to stretching vibrations of water and N-H groups [71]. This peak becomes narrower for the sample KCoFCN-1 indicating a replacement of a part of HTD by the modifier. Its presence is confirmed by a band at $2083 \mathrm{~cm}^{-1}$ (CN groups). The peak at $1615 \mathrm{~cm}^{-1}$ is attributed to bending vibrations of water; the band about $1420 \mathrm{~cm}^{-1}$ is related to ammonium. This band overlaps the peaks of Ti-OH vibrations. At last, the band lower $1000 \mathrm{~cm}^{-1}$ correspond to $\mathrm{UO}_{2}, \quad \mathrm{Ti}-\mathrm{O}$ and Ti-O-Ti vibrations. A shift of the peak at $475-479 \mathrm{~cm}^{-1}$, which is related to Ti-O vibrations, to $467 \mathrm{~cm}^{-1}$ indicates the inclusion of oxygen of these groups to coordination sphere of uranium. Decrease in the intensity of the peak at $1420 \mathrm{~cm}^{-1}$ relatively to the band of Ti-O groups (compare the spectra for pristine and loaded samples) indicates the release of $\mathrm{NH}_{4}^{+}$ions during sorption (see eqs. (4) and (7)).

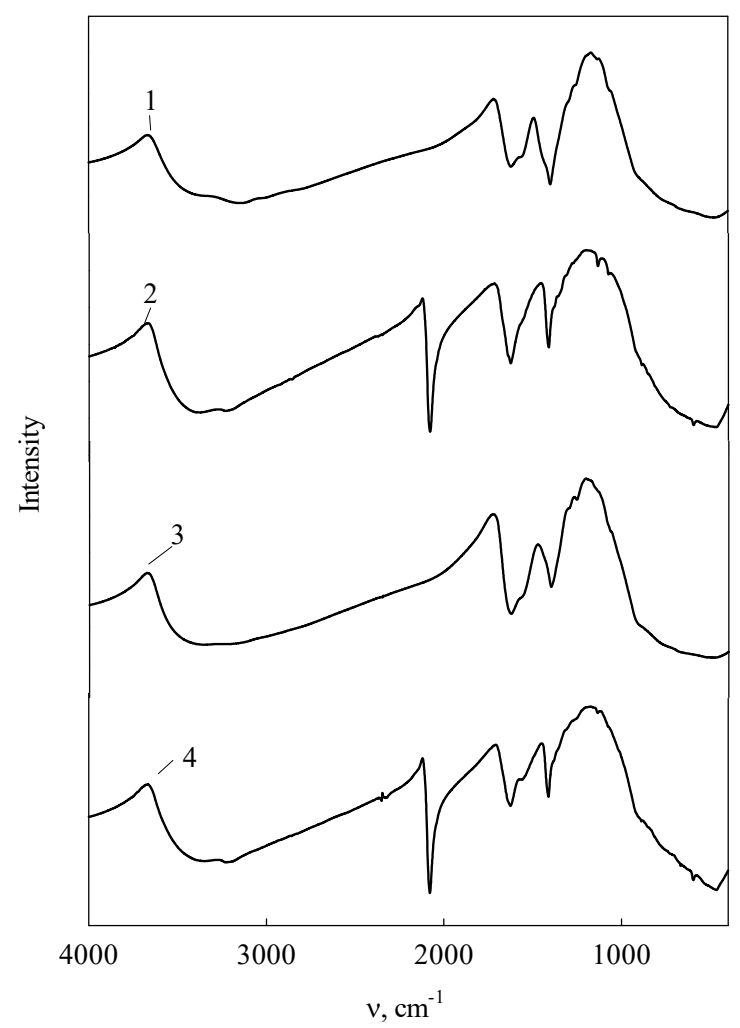

Fig. 8. FTIR spectra of pristine $(1,2)$ and loaded with $\mathrm{U}(\mathrm{VI})(3,4)$ samples of $\operatorname{HTD}(1,3)$ and HTD- KCoFCN-1 $(2,4)$. The sample contained $0.5 \mathrm{mmol} \mathrm{g}^{-1}$ of $\mathrm{U}(\mathrm{VI})(3,4)$

At last, let us consider U(VI) desorption affected by different reagents. Fig. 9 illustrates a change of sorption capacity over time. Taking into consideration high concentration of regenerating solutions, the model of particle diffusion was applied [72]. As found preliminarily, after the interruption of the contact between the sorbent and solution after $1 \mathrm{~h}$ followed by its resumption after $24 \mathrm{~h}$, the rate of sorption increased. This indicated particle diffusion as a rate-determining stage. Thus, the effective diffusion coefficient, $D$, that is related to the exchange of different ions, is estimated via:

$$
D=0.03 \frac{r^{2}}{t_{1 / 2}},
$$

where $r$ is the granule radius, $t_{1 / 2}$ is the time of half-exchange. The data are given in Table 3: the diffusion coefficient was calculated as averaged. As seen, the effect reagents on desorption is weakened in the order $\mathrm{KOH}>\mathrm{K}_{2} \mathrm{CO}_{3}>\mathrm{KHCO}_{3}$. In other words, the regeneration degree strongly 
depends on $\mathrm{pH}$. The same sequence has been found for the diffusion coefficient in HTD. At

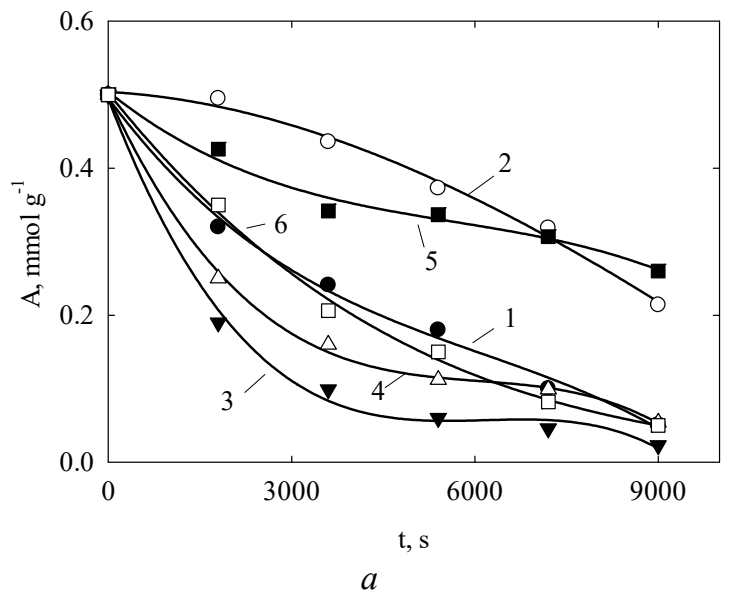

the same time, the composite is regenerated most quickly in a $\mathrm{K}_{2} \mathrm{CO}_{3}$ solution.

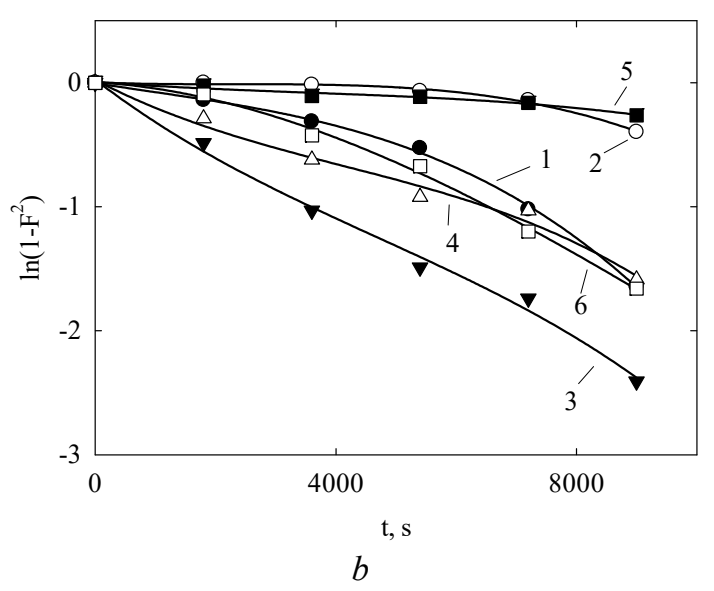

Fig. 9. Sorption capacity of HTD (1-3) and HTD- KCoFCN-1 (4-6) as a function of regeneration time (a), application of the model of particle diffusion (b). Reagents: solutions of $\mathrm{K}_{2} \mathrm{CO}_{3}(1,3), \mathrm{KHCO}_{3}(2,4), \mathrm{KOH}(3,6)$

Table 3. Desorption of U(VI) from HTD and its composite

\begin{tabular}{ccccc}
\hline Sample & Reagent & Regeneration degree, $\mathbf{\%}$ & $\boldsymbol{t}_{\mathbf{1} / \mathbf{2}}, \mathbf{s}$ & $\boldsymbol{D} \times \mathbf{1 0}^{\mathbf{1 3}}, \mathbf{m}^{\mathbf{2}} \mathbf{s}^{\mathbf{1}}$ \\
\hline \multirow{3}{*}{ HTD } & $\mathrm{K}_{2} \mathrm{CO}_{3}$ & 90 & 3873 & 2.72 \\
& $\mathrm{KHCO}_{3}$ & 58 & 6242 & 1.69 \\
& $\mathrm{KOH}$ & 96 & 1380 & 7.64 \\
\hline \multirow{3}{*}{ HTD- KCoFCN-1 } & $\mathrm{K}_{2} \mathrm{CO}_{3}$ & 88 & 1578 & 6.68 \\
& $\mathrm{KHCO}_{3}$ & 50 & 2880 & 3.66 \\
& $\mathrm{KOH}$ & 92 & 2810 & 3.75 \\
\hline
\end{tabular}

\section{CONCLUSIONS}

Here we tested the way of obtaining inorganic composites, namely synthesis of the selective constituent in the preliminary formed oxide matrix. Two methods have been proposed: the deposition of modifier in partially (hydrogel) and fully (xerogel) formed matrix. As found, a suitable way is the formation of $\mathrm{K}_{2} \mathrm{Co}\left[\mathrm{Fe}(\mathrm{CN})_{6}\right]$ in hydrogel: in this case, the modifier nanoparticles are encapsulated in oxide matrix: they are not removed during contact with liquid.

As a rule, hexacyanoferrates(II) are used for sorption of large cations of alkaline metals. The composite containing $\mathrm{K}_{2} \mathrm{Co}\left[\mathrm{Fe}(\mathrm{CN})_{6}\right]$ is promising for untraditional application removal of $\mathrm{U}(\mathrm{VI})$ compounds from aqueous solutions. The modifier sufficiently increases sorption capacity of hydrated oxide and accelerates sorption, when $\mathrm{U}(\mathrm{VI})$ is in a form of one-charged cations. The positive effect of the modifier is expressed in a presence of an excess of $\mathrm{NO}_{3}{ }^{-}, \mathrm{SO}_{4}{ }^{2-}$ and $\mathrm{Na}^{+}$ions. The composite is most completely regenerated with a $0.1 \mathrm{M} \mathrm{KOH}$ solution. Thus, the possibility of its multiple usages is assumed.

Comparing with one-component hexacyanoferrates(II), the advantage of the composite is coarseness - it can be used in sorption columns. Taking into consideration the selectivity of the modifier towards large cations of alkaline metals, the composite is assumed to be prospective for the removal of ${ }^{137} \mathrm{Cs}$ from water. 


\title{
Особливості сорбції U(VI) на композитах, що містять гідратований діоксид титану та калій-кобальт гексаціаноферрат(II)
}

\author{
О.В. Перлова, Ю.С. Дзязько, О.О. Маліновська, О.В. Пальчик
}

\author{
Одеський наиіональний університет імені I.I. Мечникова \\ вул. Дворянська, 2, 65082, Одеса, Украӥна, olga_perlova@опи.еdи.иа \\ Інститут загальної та неорганічної хімії ім. В.І.Вернадського Національної академії наук України \\ nр. Академіка Палладіна, 32/34, Київ, 03142, Україна, dzyazko@gтаil.com
}

\begin{abstract}
На відміну від полімерних сорбентів, неорганічні матеріали стійкі до іонізуючого випромінювання, що дає можливість використовувати їх для очищення води від радіонуклідів. Як правило, високоселективні неорганічні сорбенти одержують у вигляді дрібнодисперсного порошку, щуо ускладнює їх практичне використання. У роботі розроблено композити на основі гідратованого діоксиду титану, які містять калійкобальт гексаціаноферрат(II). Модифікатор вводили у частково (гідрогель) або повністю (ксерогель) сформовані оксидні матриці. Модифікація гідрогелю з наступним перетворенням його на ксерогель забезпечує утворення наночастинок гексаціаноферрату(II) калію кобальту (до 10 нм), які не вимиваються у водному середовищі через інкапсуляцію в оксидній матриці. В роботі використовувались такі методи характеристики сорбентів і результатів дослідження: трансмісійна спектроскопія для одержання ТЕМ, оптична мікроскопія для визначення розміру гранул сорбентів, ІЧ-Фур'є спектроскопія для дослідження зразків після сорбиіі урану, рентгенофлуоресцентна спектроскопія для хімічного аналізу зразків, потенціометричне титрування для встановлення pH ізоелектричного стану зразків, спектрофотометричний аналіз розчинів після сорбиії (десорбиії) для визначення U(VI) у вигляді комплекса з арсеназо III. Досліджено особливості сорбиіі U(VI) з нітратних і сульфатних розчинів: у центрі уваги знаходиться вплив дозування сорбентів та склад розчину. Найбільш суттєво вплив модифікатора виявлясться при $\mathrm{pH} \geq 4$, коли $U(V I)$ знаходиться у розчинах у вигляді однозарядних катіонів $\mathrm{UO}_{2} \mathrm{OH}^{+}$: ступінь вилучення U(VI) наближений до $100 \%$, швидкість сорбиії максимальна. Позитивний вплив селективного компонента має місце у присутності надлишку йонів $\mathrm{NO}_{3}^{-}, \mathrm{SO}_{4}^{2-}$ ma $\mathrm{Na}^{+}$. Встановлено, щзо кінетика сорбиї урану підпорядковується моделі псевдодругого порядку. Як вихіднии сорбент, так $i$ композит найбільш повно регенеруються $0.1 \mathrm{M}$ розчином КОН - ступінь десорбиії складає 92 и $96 \%$, відповідно. В изьому випадку також спостерігаються найменші значення часу напівобміну: 1380 с (вихідний сорбент) $і 2810$ с (композит). Десорбиія урану з фази композитів лімітується дифузією частинок. Розраховано коефіцієнти дифузії йонів, щуо обмінюються, які лежать у межах (1.7-7.6) $10^{-13} \mathrm{M}^{2} \mathrm{c}^{-1}$.
\end{abstract}

Ключові слова: сполуки урану(VI), гідратований діоксид титану, калій-кобальт гекаціаноферрат(II), сорбиія, наночастинки

\section{REFERENCES}

1. Hristovski K.D., Markovski J. Engineering metal (hydr)oxide sorbents for removal of arsenate and similar weak-acid oxyanion contaminants: A critical review with emphasis on factors governing sorption processes. Sci. Total Environ. 2017. 598: 258.

2. Kumar R., Chawla J. Removal of cadmium ion from water/wastewater by nano-metal oxides: a review. Water Qual. Exposure Health. 2014. 5: 215.

3. Khandare D., Mukherjee S. A review of metal oxide nanomaterials for fluoride decontamination from water environment. Mater. Today: Proc. 2019. 18(3): 1146.

4. Maltseva T.V., Kudelko E.O., Belyakov V.N. Adsorption of $\mathrm{Cu}(\mathrm{II}), \mathrm{Cd}(\mathrm{II}), \mathrm{Pb}(\mathrm{II}), \mathrm{Cr}(\mathrm{VI})$ by double hydroxides on the basis of $\mathrm{Al}$ oxide and $\mathrm{Zr}$, Sn, and Ti oxides. Russ. J. Phys. Chem. A. 2009. 83(13): 2336.

5. Kudelko K., Maltseva T., Bieliakov V. Adsorption and mobility of $\mathrm{Cu}(\mathrm{II}), \mathrm{Cd}(\mathrm{II}), \mathrm{Pb}(\mathrm{II})$ ions adsorbed on (hydr) oxide polymer sorbents $\mathrm{M}_{\mathrm{x}} \mathrm{O}_{\mathrm{y}} \bullet \mathrm{nH}_{2} \mathrm{O}, \mathrm{M}=\mathrm{Zr}(\mathrm{IV})$, Ti(IV), $\mathrm{Sn}(\mathrm{IV}), \mathrm{Mn}(\mathrm{IV})$. Desalin. Water Treat. 2011. 35(1-3): 295.

6. Trivedi P., Axe L. Predicting divalent metal sorption to hydrous Al, Fe, and Mn oxides. Environ. Sci. Technol. 2001. 35(9): 1779. 
7. Chaban M., Rozhdesvenska L., Dzyazko Yu., Ponomarova L., Palchik A. Nanocomposite sorbents based on $\mathrm{TiO}_{2}$ containing manganese spinel for concentration of lithium ions. In: Nanomaterials: Applications and Properties (NAP 2020). Proc. 2020 IEEE 10th Int. Conf. (Nov. 9-13, 2020, Sumy, Ukraine). 9309587.

8. Rozhdestvenska L.M., Chaban M.O., Dzyazko Yu.S., Palchik O.V., Dzyazko O.G. Formation of lithiumselective sorbent in nanoreactors of the support based on titanium dioxide. Appl. Nanosci. 2021. https://doi.org/10.1007/s13204-021-01832-5

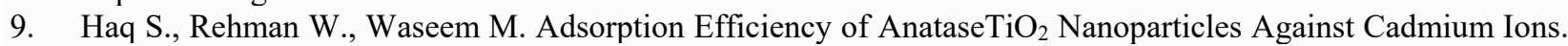
J. Inorg. Organomet. Polym. Mater. 2019. 29: 651.

10. Shi K., Luo M., Ying J., Zhen S., Xing Z., Chen R. Single-crystalline lithium manganese oxide nanotubes using ammonium peroxodisulfate. iScience. 2020. 23(11): 101768.

11. Dzyazko Yu., Rozhdestveskaya L., Zmievskii Yu., Zakharov V., Myronchuk V. Composite inorganic anion exchange membrane for electrodialytic desalination of milky whey. Mater. Today: Proc. 2019. 6(2): 250.

12. Myronchuk V., Zmievskii Yu., Dzyazko Yu., Rozhdestvenska L., Zakharov V. Whey desalination using polymer and inorganic membranes: operation conditions. Acta Periodica Technologica. 2018. 49: 103.

13. Martí-Calatayud M.C., García-Gabaldón M., Pérez-Herranz V., Sales S., Mestre S. Ceramic anion-exchange membranes based on microporous supports infiltrated with hydrated zirconium dioxide. $R S C A d v$. 2015. 5(57): 46348.

14. Mora-Gómez J., García-Gabaldón M., Martí-Calatayud M.C., Mestre S., Pérez-Herranz V. Anion transport through ceramic electrodialysis membranes made with hydrated cerium dioxide. J. Am. Ceram. Soc. 2017. 100(9): 4180.

15. Dzyazko Y.S., Rozhdestvenska L.M., Vasilyuk S.L., Kudelko K.O., Belyakov V.N. Composite membranes containing nanoparticles of inorganic ion exchangers for electrodialytic desalination of glycerol. Nanoscale Res. Lett. 2017. 12(1): 438.

16. Saki S., Uzal N., Ates N. The size and concentration effects of $\mathrm{Al}_{2} \mathrm{O}_{3}$ nanoparticles on PSF membranes with enhanced structural stability and filtration performance. Desalin. Water Treat. 2017. 84: 215.

17. Pang R., Li X., Li J., Sun X., Wang L. Preparation and characterization of $\mathrm{ZrO}_{2} / \mathrm{PES}$ hybrid ultrafiltration membrane with uniform $\mathrm{ZrO}_{2}$ nanoparticles. Desalination. 2014. 332(1): 60.

18. Zheng Y.-M., Zou S.-W., Nadeeshani Nanayakkara K.G., Matsuura T., Chen J. Adsorptive removal of arsenic from aqueous solution by a PVDF/zirconia blend flat sheet membrane. J. Membr. Sci. 374(1-2) 1.

19. Perlova N., Dzyazko Y., Perlova O., Palchik A., Sazonova V. Formation of Zirconium Hydrophosphate Nanoparticles and Their Effect on Sorption of Uranyl Cations. Nanoscale. Res. Lett. 2017. 12: 209.

20. Perlova O., Dzyazko Yu., Halutska I., Perlova N., Palchik A. Anion exchange resin modified with nanoparticles of hydrated zirconium dioxide for sorption of soluble U(VI) compounds. In: Nanooptics, Nanophotonics, Nanostructures, and Their Applications. (Springer International Publishing AG, part of Springer Nature, 2018).

21. Maltseva T.V., Kolomiets E.O., Dzyazko Yu.S., Scherbakov S. Composite anion-exchangers modified with nanoparticles of hydrated oxides of multivalent metals. Appl. Nanosci. 2019. 9(5): 997.

22. Kolomiyets Y.O., Belyakov V.N., Palchik A.V., Maltseva T.V., Zheleznova L.I. Adsorption of arsenic by hybrid anion-exchanger based on titanium oxyhydrate. J. Water Chem. Technol. 2017. 39(2): 80.

23. Dzyazko Yu., Kolomyets E., Borysenko Yu., Chmilenko V., Fedina I. Organic-inorganic sorbents containing hydrated zirconium dioxide for removal of chromate anions from diluted solutions. Mater. Today: Proc. 2019. 6(2): 260.

24. Chouyyok W., Pittman J.W., Warner M.G., Nell K.M., Clubb D.C., Gill G.A., Addleman R.S. Surface functionalized nanostructured ceramic sorbents for the effective collection and recovery of uranium from seawater. Dalton Trans. 2016. 45(28): 11312.

25. Mahmoud M.E., Abou Ali S.A.A., Elweshahy S.M.T. Microwave functionalization of titanium oxide nanoparticles with chitosan nanolayer for instantaneous microwave sorption of $\mathrm{Cu}(\mathrm{II})$ and $\mathrm{Cd}(\mathrm{II})$ from water. Int. J. Biol. Macromol. 2018. 111: 393.

26. Ide A., Drisko G.L., Scales N., Luca V., Schiesser C.H., Caruso R.A. Monitoring bisphosphonate surface functionalization and acid stability of hierarchically porous titanium zirconium oxides. Langmuir. 2011. 27(21): 12985.

27. Liu G., Wu C., Zhang X., Liu Y., Meng H., Xu J., Han Y., Xu X., Xu Y. Surface functionalization of zirconium dioxide nano-adsorbents with 3-aminopropyl triethoxysilane and promoted adsorption activity for bovine serum albumin. Mater. Chem. Phys. 2016. 176: 129.

28. Vallée A., Faga M.G., Mussano F., Catalano F., Tolosano E., Carossa S., Altruda F., Martra G. Aluminazirconia composites functionalized with laminin-1 and laminin-5 for dentistry: effect of protein adsorption on cellular response. Colloids Surf. B. Biointerfaces. 2014. 114: 284. 
29. Danalığlu S.T., Bayazit S.S., Kerkez O.K., Salam Mohamed Abdel S.M. Efficient removal of antibiotics by a novel magnetic adsorbent: Magnetic activated carbon/chitosan (MACC) nanocomposite. J. Mol. Liq. 2017. 240: 589.

30. Mahmoud M.E., Abdelwahab M.S., Fathallah E.M. Design of novel nano-sorbents based on nano-magnetic iron oxide-bound-nano-silicon oxide-immobilized-triethylenetetramine for implementation in water treatment of heavy metals. Chem. Eng. J. 2013. 223: 318.

31. Zheng Y.M., Lim S.F., Chen J.P. Preparation and chN.,aracterization of zirconium-based magnetic sorbent for arsenate removal. J. Colloid Interface Sci. 2009. 338(1): 22.

32. Egorin A., Tokar E., Matskevich A., Ivanov N., Tkachenko I., Sokolnitskaya T., Zemskova L. Composite Magnetic Sorbents Based on Iron Oxides in Different Polymer Matrices: Comparison and Application for Removal of Strontium. Biomimetics. 2020. 5(2): 22.

33. Panasenko A., Pirogovskaya P., Tkachenko I., Ivannikov S., Arefieva O., Marchenko Y. Synthesis and characterization of magnetic silica/iron oxide composite as a sorbent for the removal of methylene blue. Mater. Chem. Phys. 2020. 245: 122759.

34. Perlova O.V., Ivanova I.S., Dzyazko Yu.S., Danilov M.O., Rusetskii I.A., Kolbasov G.Ya. Sorption of U(VI) compounds on inrganic composites containing partially unzipped multiwalled nanotubes. Him. Fiz. Tekhnol. Surf. 2021. 12(1): 16.

35. Perlova O.V., Dzyazko Yu.S., Palchik A.V., Ivanova I.S., Perlova N.O., Danilov M.O., Rusetskii I.A., Kolbasov G.Ya., Dzyazko A.G. Composites based on zirconium dioxide and zirconium hydrophosphate containing graphene-like additions for removal of U(VI) compounds from water. Appl. Nanosci. 2020. 10(12): 45.

36. Zhang K., Dwivedi V., Chi C., Wu J. Graphene oxide/ferric hydroxide composites for efficient arsenate removal from drinking water. J. Hazard. Mater. 2010. 182(1-3): 162.

37. Luo X., Wang X., Bao S., Liu X., Zhang W., Fang T. Adsorption of phosphate in water using one-step synthesized zirconium-loaded reduced graphene oxide. Sci. Rep. 2016. 6: 39108.

38. Cui L., Wang Y., Gao L., Hu L., Yan L., Wei Q., Du B. EDTA functionalized magnetic graphene oxide for removal of $\mathrm{Pb}(\mathrm{II}), \mathrm{Hg}(\mathrm{II})$ and $\mathrm{Cu}(\mathrm{II})$ in water treatment: Adsorption mechanism and separation property. Chem. Eng. J. 2015. 281: 1.

39. Seredych M., Bandosz T.J. Reactive adsorption of hydrogen sulfide on graphite oxide $/ \mathrm{Zr}(\mathrm{OH})_{4}$ composites. Chem. Eng. J. 2011. 166(3): 1032.

40. Myronchuk V., Zmievskii Y., Dzyazko Y., Rozhdestveska L., Zakharov V., Bildyukevich A. Electrodialytic whey demineralization involving polymer-inorganic membranes, anion exchange resin and graphene-containing composite. Acta Periodica Technologica. 2019. 50: 163.

41. Nguyen-Phan T.-D., Pham V.H., Shin F.W., Pham H.-D., Kim S., Chung J.K., Kim E.J., Hur S.H. The role of graphene oxide content on the adsorption-enhanced photocatalysis of titanium dioxide/graphene oxide composites. Chem. Eng. J. 2011. 170(1): 226.

42. Prout W.E., Russel E.R., Groh H.J. Ion exchange adsorption of cesium by potassium hexacyanocobalt(II) ferrate (II). J. Inorg. Nucl. Chem. 1965. 27(2): 473.

43. Kawamura S., Shibata S., Kurotaki K., Takeshita H. The sorption characteristics of radionuclides on copper hexacyanoferrate(II), and the determination of ${ }^{137} \mathrm{Cs}$ in sea water. Anal. Chim. Acta. 1978. 102: 225.

44. Qing Y.H., Li J., Kang B., Chang S.Q., Dai Y.D., Long Q., Yuan C. Selective sorption mechanism of Cs ${ }^{+}$on potassium nickel hexacyanoferrate(II) compounds. J. Radioanal. Nucl. Chem. 2015. 304: 527.

45. Petersková M., Valderrama C., Oriol G., Cortina J.L. Extraction of valuable metal ions (Cs, Rb, Li, U) from reverse osmosis concentrate using selective sorbents. Desalination. 2012. 286: 316.

46. Loos-Neskovic C., Ayrault S., Badillo V., Jimenez B., Garnier E., Fedoroff M.D., Jones J., Merinov B. Structure of copper-potassium hexacyanoferrate (II) and sorption mechanisms of cesium. J. Solid State Chem. 2004. 177(6): 1817.

47. Paolella A., Faure C., Timoshevskii V., Marras S., Bertoni G., Guerfi A., Vijh A., Armand M., Zaghib K. A review on hexacyanoferrate-based materials for energy storage and smart windows: challenges and perspectives. J. Mater. Chem. A. 2017. 5(36): 18919.

48. Mullaliu A., Giorgetti M. Metal Hexacyanoferrates: Ion Insertion (or Exchange) Capabilities. In: Applications of Ion Exchange Materials in the Environment. (Cham: Springer, 2019).

49. Naidu G., Nur T., Paripurnanda T., Jaya L., Kandasamy J., Vigneswaran S. Selective sorption of rubidium by potassium cobalt hexacyanoferrate. Sep. Purif. Technol. 2016. 163: 238.

50. Yang Y., Faustino P.J., Progar J.J., Brownell C.R., Sadrieh N., May J.C., Leutzinger E., Place D.A., Duffy E.P., Yu L.X., Khan M.A., Lyon R.C. Quantitative determination of thallium binding to ferric hexacyanoferrate: Prussian blue. Int. J. Pharm. 2008. 353(1-2): 187. 
51. Pshinko G.N., Puzyrnaya L.N., Yatsik B.P., Kosorukov A.A. Removal of U(VI) from aqueous media with layered double hydroxide of $\mathrm{Zn}$ and $\mathrm{Al}$, intercalated with hexacyanoferrate(II) ions. Radiochemistry. 2015. 57(6): 616.

52. Polyakov E.V., Volkov I.V., Khelbnikov N.A. Competitive Sorption of Ions of Cesium and Other Microelements onto Iron(III) Hexacyanoferrate (II) in the Presence of Humic Acids. Radiochemistry. 2015. 57(2): 161.

53. Perlova O.V., Dzyazko Yu.S., Palchik O.V., Martovyi I.S. Hydrated titanium dioxide modified with potassium cobalt hexacyanoferrate (II) for sorption of cationic and anionic complexes of uranium(VI). Appl. Nanosci. 2021. https://doi.org/10.1007/s13204-021-01721-X

54. Voronina A.V., Kulyaeva I.O., Gupta D.K. Determination of the parameters of selective ${ }^{137}$ Cs sorption onto natural and ferrocyanide-modified glauconite and clinoptilolite. Radiochemistry. 2018. 60: 35.

55. Zhang H., Kim Y.K., Hunter T.N., Andrew P., Brown A.P., Lee J.W., Harbottle D. Organically modified clay with potassium copper hexacyanoferrate for enhanced $\mathrm{Cs}^{+}$adsorption capacity and selective recovery by flotation. J. Mater. Chem. A. 2017. 5(29): 15130.

56. Alamudy H.A., Cho K. Selective adsorption of cesium from an aqueous solution by a montmorillonite-prussian blue hybrid. Chem. Eng. J. 2018. 349: 595.

57. Lee H.K., Yang D.S., Oh W., Cho S.J. Copper ferrocyanide functionalized core-shell Magnetic Silica Compositesfor the Selective Removal of Cesium Ions from radioactive liquid waste. J. Nanosci. Nanotechnol. 2016. 16(6): 6223.

58. Michel C., Barré Y., Guiza M., Dieuleveult C., Windt I., Grandjean A. Breakthrough studies of the adsorption of Cs from fresh water using a mesoporous silica material containing ferrocyanide. Chem. Eng. J. 2018. 339: 288.

59. Mahmoud M.R., Seliman A.F. Evaluation of silica/ferrocyanide composite as a dual-function material for simultaneous removal of ${ }^{137} \mathrm{Cs}^{+}$and ${ }^{99} \mathrm{TcO}_{4}{ }^{-}$from aqueous solutions. Appl. Radiat. Isot. 2014. 91 : 141.

60. Galysh V.V., Kartel M.T., Milyutin V.V., Pakhlov E.M., Oranska O.I., Gornikov Y.I. Composite celluloseinorganic sorbents for ${ }^{137} \mathrm{Cs}$ recovery. J. Radioanal. Nucl. Chem. 2014. 301(2): 315.

61. Galysh V.V., Kartel M.T., Milyutin V.V. Synthesis and sorption properties of combined cellulose-inorganic sorbents for the concentration of cesium-137. Surface. 2013. 5(20): 135.

62. Galysh V.V., Kartel M.T. Modification of cellulose and lignocellulose materials with nanoclusters of copper ferrocyanides. Him. Fiz. Tekhnol. Poverhni. 2014. 5(4): 438.

63. Kiener J., Limousy L., Jeguirim M., Meins J.M., Hajjar-Garreau S., Bigoin G., Ghimbeu C.M. Activated carbon/transition metal (Ni, In, Cu) hexacyanoferrate nanocomposites for cesium adsorption. Materials. 2019. 12(8): 1253.

64. Li J., Zan Y., Zhang Z., Dou M., Wang F. Prussian blue nanocubes decorated on nitrogen-doped hierarchically porous carbon network for efficient sorption of radioactive cesium. J. Hazard. Mater. 2020. 385: 121568.

65. Lee J.H., Suh D.H. Entropy, enthalpy, and Gibbs free energy variations of ${ }^{133} \mathrm{Cs}$ via $\mathrm{CO}_{2}$-activated carbon filter and ferric ferrocyanide hybrid composites. Nucl. Eng. Technol. 2021. 53(11): 3711.

66. Chaban M.O., Rozhdestvenska L.M., Palchik O.V., Ponomarova L.M., Dzyazko Y.S. Selective to lithium ions nanocomposite sorbents based on $\mathrm{TiO}_{2}$ containing manganase spinel. Voprosy Khimii $i$ Khimicheskoi Tekhnologii. 2021. (4): 126.

67. Kadam B.V., Maiti B., Sathe R.M. Selective spectrophotometric method for the determination of uranium(VI). Analyst. 1981. 106(1263): 724.

68. Nazarenko V.A., Antonovich V.P., Nevskaya E.M. Hydrolysis of metal ions in diluted solutions. (Moscow: Atomizdat, 1979). [in Russian].

69. Perlova O.V., Shirykalova A.A. Flotoextraction removal of uranium(VI) using fine emulsified solutions of trialkylamine in white spirit. J. Water Chem. Technol. 2008. 30(3): 385.

70. Ho Y.S., McKay G. Pseudo-second order model for sorption processes. Process Biochem. 1999. 34(5): 451.

71. Nakamoto K. Infrared and raman spectra of inorganic and coordination compounds: part a: theory and applications in inorganic chemistry. 6th Edn. (Hoboken, Wiley, 2008).

72. Helfferich F. Ion Exchange. (New York: Dover, 1995). 